Vol. 1 No. 2 Agustus 2021 e-ISSN : 2797-1031 | p-ISSN : 2797-0744

\title{
PENGARUH MODEL PEMBELAJARAN REALISTIK MATHEMATIC EDUCATION (RME) DAN PROBLEM POSING SERTA KEMAMPUAN AWAL SISWA TERHADAP HASIL BELAJAR MATEMATIKA
}

\author{
EVI MAFIDAH \\ Madrasah Aliyah Negeri 1 Tuban \\ e-mail: mafidahevi@gmail.com
}

\begin{abstract}
ABSTRAK
Matematika sebagai ilmu dasar memegang peranan yang sangat penting dalam pengembangan sains dan teknologi, karena matematika merupakan sarana berpikir untuk menumbuh kembangkan daya nalar, cara berpikir logis, sistematis dan kritis. Pembelajaran matematika seringkali menggunakan urutan sajian: diajarkan teori/ definisi/ teorema, diberikan contoh-contoh, dan diberikan latihan soal. Pembelajaran seperti ini kurang melibatkan partisipasi aktif siswa sehingga hasil belajarnya kurang maksimal. Salah satu model pembelajaran yang diharapkan dapat meningkatkan peran aktif serta pemahaman siswa terhadap mata pelajaran yaitu model pembelajaran Realistic Mathematic Education (RME). Model pembelajaran lain yang dapat digunakan untuk mengatasi permasalahan yang ada, diantaranya model pembelajaran problem posing. Penelitian ini termasuk dalam penelitian eksperimen dengan besar populasi 135 dan besar sampel 72. Pengumpulan data dilakukan dengan teknik tes dan analisis data dilakukan menggunakan analisis varian dua faktor (anava).Hasil penelitian menunjukkan bahwa: (1)ada perbedaan hasil belajar Matematika antara kelompok siswa yang diberi perlakuan menggunakan model pembelajaran Realistic Mathematic Education (RME) dan Problem Possing, (2) hasil belajar Matematika antara kelompok siswa yang memiliki kemampuan awal tinggi dan kemampuan awal rendah, (3) ada interaksi antara model pembelajaran Realistic Mathematic Education (RME) dan Problem Possing serta kemampuan awal siswa terhadap hasil belajar matematika.
\end{abstract}

Kata kunci: Model Pembelajaran, Realistic Mathematic Education, Problem Posing,

Kemampuan Awal, Hasil Belajar

\section{PENDAHULUAN}

Pembelajaran bukanlah suatu konsep atau praktik yang sederhana, melainkan bersifat kompleks dan menjadi tugas, serta tangggung jawab guru dalam membelajarkan peserta didiknya. Pengelolaan pembelajaran yang baik harus dikembangkan berdasarkan prinsipprinsip pengelolaan dan prinsip-prinsip pembelajaran. Namun, dalam praktiknya permasalahan sering terjadi dalam pembelajaran, apakah itu bersumber dari kemampuan guru dalam mengajar atau input siswa bahkan dari unsur-unsur pendukung lainnya.Secara praktis, guru adalah ujung tombak dalam kegiatan pembelajaran. Strategi dan manajemen guru untuk mengatasi masalah pembelajaran sangat dibutuhkan dalam upaya meningkatkan kualitas pembelajaran. Pelaksanaan pembelajaran di dalam kelas merupakan salah satu tugas utama guru. Pembelajaran dapat diartikan sebagai kegiatan yang ditujukan untuk membelajarkan siswa, karenanya dalam proses pembelajaran mestinya harus ada keterlibatan siswa. Dominasi guru dalam proses pembelajaran menyebabkan kecenderungan siswa lebih bersifat pasif sehingga mereka lebih banyak menunggu sajian guru dari pada mencari dan menemukan sendiri pengetahuan, ketrampilan atau sikap yang mereka butuhkan.

Matematika merupakan salah satu mata pelajaran wajib yang diajarkan di tingkat SD sampai SMA. Upaya peningkatan kualitas pendidikan matematika di Indonesia dilakukan dengan berbagai cara, antara lain melalui pembaharuan kurikulum dan penyediaan perangkat pendukungnya seperti silabus, buku siswa, dan buku pedoman untuk guru. Matematika sebagai ilmu dasar memegang peranan yang sangat penting dalam pengembangan sains dan teknologi, karena matematika merupakan sarana berpikir untuk menumbuh kembangkan daya nalar, cara 
berpikir logis, sistematis dan kritis. Peranan matematika tidak hanya terasa dalam bidang matematika tetapi aplikasinya juga pada bidang lain.

Hasil observasi berlangsungnya kegiatan pembelajaran matematika di MAN 1 Tuban menunjukkan bahwa proses pembelajaran matematika belum menggunakan metode pembelajaran yang interaktif. Pembelajaran matematika selama ini seringkali menggunakan urutan sajian sebagai berikut: (1) diajarkan teori/ definisi/ teorema, (2) diberikan contoh-contoh, (3) diberikan latihan soal. Pembelajaran semacam ini biasa disebut dengan pembelajaran konvensional. Banyak temuan di lapangan maupun peneliti yang mengindikasikan bahwa pembelajaran matematika secara konvensional itu berakibat negatif dan tidak membelajarkan siswa secara bermakna. Hal ini mengakibatkan kurangnya aktivitas siswa saat proses belajar mengajar.

Siswa dalam proses belajar mengajar yang sangat rendah dan pasif membuat suasana kelas menjadi tidak hidup sehingga berdampak pada tingkat pemahaman peserta didik terhadap materi yang disampaikan oleh guru. Siswa yang kurang berminat belajar matematika akan cepat bosan dan tidak tertarik terhadap pembelajaran ketika guru menyampaikan materi Matematika sehingga tidak berkonsentrasi penuh pada pembelajaran yang berlangsung dan kelas menjadi tidak kondusif. Keadaan ini menunjukkan bahwa suasana proses belajar mengajar kurang menyenangkan sehingga siswa mencari kesenangan sendiri daripada memperhatikan materi yang diberikan guru. Apalagi jika keingintahuan siswa tentang materi juga sangat rendah.

Berdasarkan hasil wawancara dengan guru pengampu mata pelajaran matematika di MAN 1 Tuban, hasil evaluasi belajar matematika siswa pada semester ganjil tahun pelajaran 2019-2020 menunjukkan rata-rata nilai ulangan harian masih dibawah Kriteria Ketuntasan Minimal (KKM) yang diharapkan yaitu 75. Hal ini terlihat pada rata-rata nilai Ulangan Harian matematika yang diperoleh kelas XI IPA yaitu 65,4.Rendahnya prestasi belajar matematika yang dicapai siswa tersebut dipengaruhi oleh banyak faktor, baik internal maupun eksternal. Salah satu faktor adalah siswa mengalami masalah secara komprehensif atau secara parsial dalam matematika. Selain itu belajar matematika siswa belum bermakna, sehingga pengertian siswa tentang konsep sangat lemah. Belajar matematika merupakan belajar konsep. Hal yang paling penting adalah bagaimana siswa dapat memahami konsep-konsep dasar dalam matematika. Maka dalam proses belajar mengajar siswa diharapkan tidak hanya mendengarkan, mencatat dan menghafalkan materi maupun rumus-rumus yang diberikan guru, melainkan siswa dituntut aktif berperan dalam kegiatan pembelajaran, siswa harus mampu berpikir kritis dan berargumen dalam memecahkan berbagai persoalan dalam matematika.

Melihat kondisi pembelajaran serta nilai hasil belajar siswa dalam belajar matematika dapat juga disebabkan oleh faktor intern dari dalam diri siswa. Faktor intern tersebut dapat berupa minat belajar siswa dalam pelajaran matematika yang masih rendah, motivasi belajar yang rendah, atau kemampuan awal matematika siswa juga rendah. Menurut (Muhibbin Syah, 2006:121) kemampuan awal siswa adalah kemampuan yang telah dipunyai siswa sebelum mengikuti pembelajaran yang akan diberikan. Kemampuan awal ini menggambarkan kesiapan siswa dalam menerima pelajaran yang akan disampaikan oleh guru. Kemampuan awal siswa penting untuk diketahui guru sebelum ia memulai dengan pembelajarannya, karena dengan demikian dapat di ketahui apakah siswa telah mempunyai pengetahuan yang merupakan prasyarat untuk mengikuti pembelajaran sejauh mana siswa telah mengetahui materi apa yang akan disajikan.

Metode pembelajaran merupakan salah satu penunjang keberhasilan dalam tercapainya tujuan pendidikan. Penggunaan metode pembelajaran yang tepat memiliki peran besar dalam kesuksesan pembelajaran. Pemilihan metode pembelajaran yang tepat akan membuat proses pembelajaran lebih menarik perhatian siswa, sehingga siswa akan merasa senang untuk mengikuti pelajaran dan merekapun akan memperhatikan apa yang disampaikan oleh guru. Siswa pun akan lebih berpartisipasi aktif dalam pembelajaran dan rasa ingin tahu terhadap pembelajaran juga lebih positif. Metode pembelajaran juga membuat proses mendidik lebih 
bervariasi sehingga siswa tidak bosan dan tidak ada yang mengantuk saat pembelajaran berlangsung sehingga pemahaman akan materi yang dipelajari pun semakin baik

Banyak sekali model atau metode pembelajaran yang bisa digunakan oleh guru dalam kegiatan belajar mengajar matematika. Pemilihan model pembelajaran juga hendaknya harus disesuaikan dengan tujuan pembelajaran, materi, kemampuan guru, karakteristik siswa, dan kondisi lingkungan belajar. Salah satu model pembelajaran yang dapat membangkitan minat belajar serta pemahaman peserta didik terhadap mata pelajaran yaitu model pembelajaran Realistic Mathematic Education (RME). Menurut (Shadiq \& Mustajab, 2010: 7) pembelajaran RME adalah model pembelajaran matematika yang mengungkapkan pengalaman dan kejadian yang dekat dengan siswa sebagai sarana untuk memahamkan persoalan matematika. Dengan menggunakan model pembelajaran RME yang memiliki prinsip bahwa mengajarkan Matematika harus dimulai dari hal yang bersifat kontekstual, siswa akan lebih mudah memahami materi Matematika sehingga siswa tidak akan mengalami kesulitan memahami materi yang bersifat abstrak, yang dikutip dari Soedjadi (dalam Hobri, 2009:161).Model pembelajaran lain yang dapat digunakan untuk mengatasi permasalahan yang ada, diantaranya model pembelajaran problem posing. Pada prinsipnya, menurut (Suyatno,2009:60; Thobroni \& Arif, 2011:343; Mahmudi, 2008:4) model pembelajaran problem posing merupakan suatu model pembelajaran yang mewajibkan para siswa untuk mengajukan soal sendiri melalui pelajaran soal (berlatih soal secara mandiri). Secara bertahap siswa akan dapat mengkonstruksi sendiri pengetahuannya mengenai konsep matematika yang sedang dipelajarinya karena diberi kesempatan mengajukan soal sendiri.

\section{METODE PENELITIAN}

Penelitian ini dimaksudkan untuk mencari pengaruh suatu variabel terhadap variabel lain, maka ketegori atau desain penelitian ini adalah eksperimen dengan menggunakan rancangan eksperimen faktorial $(2 \times 2)$, seluruh hipotesis yaitu adanya pengaruh model pembelajaran terhadap hasil belajar siswa antara yang diajar menggunakan model pembelajaran RME dengan model pembelajaran problem posing, antara siswa yang memiliki kemampuan awal tinggi dengan rendah, dan interaksi antara kedua variabel tersebut akan dapat diuji sekaligus. Sampel penelitian ini ditentukan dengan menggunakan Simple Random Sampling (sampel acak sederhana) dengan cara undian. Jumlah populasi (N) sebanyak empat kelas XII IPA, maka setelah diundi kelas yang terpilih adalah kelas XII IPA 2 dan XII IPA 4 sehingga besar sampel adalah 2 kelas. Dari 2 kelas IIX IPA MAN I Tuban, diambil satu kelas diajar menggunakan model pembelajaran RME dan satu kelas lagi diajar menggunakan model pembelajaran problem posing dengan cara diundi.Instrumen yang digunakan adalah instrumen soal tes kemampuan awal dan soal tes hasil belajar. Hasil uji coba instrumen sebelum dilaksanakan penelitian adalah sebagai berikut:

A. Uji validitas dengan analisis Korelasi Pearson Dalam Kriteria yang digunakan adalah jika menghasilkan signifikansi lebih kecil dari 0,05 ( $\alpha=5 \%)$ maka butir pernyataan valid, dan sebaliknya jika korelasi pearson menghasilkan nilai signifikansi lebih besar dari 0,05 (5\%) maka butir pernyataan dinyatakan tidak valid.

B. Uji reliabilitas (uji kehandalan) tes. Untuk mengukur reliabilitas digunakan nilai Alpha Cronbach dengan menggunakan bantuan komputer program SPSS versi 20 Jika koefisien Alpha Cronbach lebih besar dari 0,60, maka instrumen dianggap reliabel.

Uji prasyarat sebelum uji hipotesis menggunkan uji normalitas dan uji homogenitas. Pengujian masing-masing persyaratan dengan menggunakan taraf signifikan 5\%, sedangkan Uji hipotesis dalam penelitian ini ada tiga dan diuji sekaligus dengan menggunakan analisis varians dua faktor atau anava.

\section{HASIL DAN PEMBAHASAN}

Data dari hasil penelitian didapatkan ringkasan statistiknya pada tabel sebagai berikut: 
Vol. 1 No. 2 Agustus 2021 e-ISSN : 2797-1031 | p-ISSN : 2797-0744

Tabel 1 Data deskripsi statistik hasil penelitian

Statistics

\begin{tabular}{|c|c|c|c|c|}
\hline & $\begin{array}{l}\text { Hasil Belajar } \\
\text { RME }\end{array}$ & $\begin{array}{l}\text { Hasil Belajar } \\
\text { Problem } \\
\text { Posing }\end{array}$ & $\begin{array}{l}\text { Kemampuan } \\
\text { Awal RME }\end{array}$ & $\begin{array}{l}\text { Kemampuan } \\
\text { Awal } \\
\text { Problem } \\
\text { Posing }\end{array}$ \\
\hline Valid & 36 & 36 & 36 & 36 \\
\hline Missing & 36 & 36 & 36 & 36 \\
\hline Mean & 84,44 & 79,31 & 77,64 & 75,00 \\
\hline Median & 85,00 & 80,00 & 80,00 & 75,00 \\
\hline Mode & 90 & 80 & 85 & 70 \\
\hline Std. Deviation & 8,683 & 6,882 & 7,972 & 8,619 \\
\hline Minimum & 65 & 65 & 65 & 60 \\
\hline Maximum & 100 & 90 & 90 & 90 \\
\hline Sum & 3040 & 2855 & 2795 & 2700 \\
\hline
\end{tabular}

Tabel 2. Hasil Analisis Varians Dua Faktor

Dependent Variable: Hasil Belajar

\begin{tabular}{llllll}
\hline Source & $\begin{array}{l}\text { Type III } \\
\text { Sum of df } \\
\text { Squares }\end{array}$ & $\begin{array}{l}\text { Mean } \\
\text { Square }\end{array}$ & F & Sig. \\
\hline Corrected Model & $1268,264^{\mathrm{a}}$ & 3 & 422,755 & 7,481 & 0 \\
Intercept & 444070,5 & 1 & 444070,5 & 7857,922 & 0 \\
Modelpembelajaran & 255,524 & 1 & 255,524 & 4,522 & 0,037 \\
Kemampuanawal & 434,912 & 1 & 434,912 & 7,696 & 0,007 \\
Modelpembelajaran & 409,383 & 1 & 409,383 & 7,244 & 0,009 \\
* Kemampuanawal & 3842,848 & 68 & 56,512 & & \\
Error & 478800 & 72 & & & \\
Total & 5111,111 & 71 & & & \\
Corrected Total & & & & \\
\hline
\end{tabular}

a.R Squared $=, 248$ (Adjusted R Squared $=, 215$ )

1. Perbedaan Hasil Belajar Matematika antara kelompok siswa yang diberi perlakuan menggunakan model pembelajaran Realistic Mathematic Education (RME) dan Problem Possing

Dari hasil uji Anava pada tabel 2. menunjukkan F hitung pada model pembelajaran adalah 4,522 dengan probabilitas sebesar 0,037 < 0,05. Hal ini menunjukkan bahwa ada perbedaan hasil belajar Matematika antara kelompok siswa yang diberi perlakuan menggunakan model pembelajaran Realistic Mathematic Education (RME) dan Problem Possing pada siswa.Hasil uji hipotesis pertama di atas dapat diinterpretasikan bahwa faktor model pembelajaran membawa pengaruh yang signifikan terhadap hasil belajar, karena dalam proses belajar mengajar sangat diperlukan variasi model pembelajaran. Dalam penelitian ini rata-rata hasil belajar Matematila dengan model pembelajaran RME adalah 84,44, sedangkan rata-rata hasil belajar dalam pembelajaran problem posing adalah 79,31 yang ditunjukkan pada tabel 1. Dari hasil rata-rata kedua model pembelajaran tersebut, maka dapat disimpulkan bahwa hasil belajar Matematika siswa yang diajar menggunakan model pembelajaran RME lebih tinggi daripada hasil belajar Matematika siswa yang diajar menggunakan model pembelajaran problem posing .

Temuan ini didukung oleh hasil penelitian (Sugiyanti, 2006) bahwa Pembelajaran Realistic Mathematic Education (RME) menghasilkan prestasi belajar matematika lebih baik dibandingkan dengan pembelajaran konvensional, selain itu siswa yang mempunyai kemampuan awal tinggi menghasilkan prestasi belajar yang lebih baik dibandingkan dengan 
siswa yang mempunyai kemampuan awal rendah. Demikian juga (Ratnasari \& Renni Eka, 2014) bahwa ada pengaruh Realistic Mathematic Education terhadap hasil belajar materi dimensi tiga siswa kelas X MA Bandung Tulungagung Tahun Pelajaran 2013/2014. Hal ini ditunjukkan dengan rata-rata nilai hasil belajar dari kelas eksperimen adalah 86,88 sedangkan kelas kontrol $=76,25$, jadi kelas eksperimen lebih tinggi daripada kelas kontrol.

\section{Perbedaan Hasil Belajar Matematika antara Kelompok Siswa yang Memiliki Kemampuan Awal Tinggi dan Kemampuan Awal Rendah}

Dari hasil uji Anava dalam tabel 2 pada F hitung untuk kemampuan awal adalah sebesar 7,696 dengan probabilitas sebesar 0,007<0,05, maka Ho ditolak. Hal ini menunjukkan bahwa ada perbedaan hasil belajar Matematika antara kelompok siswa yang memiliki kemampuan awal tinggi dan kemampuan awal rendah pada siswa.Dalam penelitian ini rata-rata (mean) dari hasil belajar Matematika siswa-siswi yang memiliki kemampuan awal tinggi lebih baik dibandingkan hasil belajar siswa yang memiliki kemampuan awal rendah. Pada tabel 1 rata-rata (mean) hasil belajar matematika dari kelompok siswa yang memiliki kemampuan awal tinggi adalah 83,23, sedangkan rata-rata hasil belajar dari kelompok siswa yang memiliki kemampuan awal rendah adalah 78,181. Dari rata-rata hasil belajar kedua kelompok siswa tersebut, maka dapat disimpulkan bahwa siswa yang memiliki kemampuan awal tinggi nilai hasil belajarnya lebih baik daripada siswa yang memiliki kemampuan awal rendah. Dari hasil uji hipotesis kedua di atas dapat diinterpretasikan bahwa faktor kemampuan awal siswa dapat membawa pengaruh yang signifikan terhadap hasil belajar. Hal ini didukung oleh hasil penelitian (Ratna, 2014) bahwa siswa berkemampuan awal tinggi memperoleh hasil belajar yang lebih baik dibandingkan dengan siswa yang berkemampuan awal rendah.

\section{Interaksi antara Model Pembelajaran Realistic Mathematic Education (RME) dan Problem Possing serta Kemampuan Awal Siswa terhadap Hasil Belajar Matematika}

Dari tabel 2 diperoleh bahwa nilai $F$ hitung untuk interaksi model pembelajaran dan kemampuan awal adalah sebesar 7,244 dengan probabilitas sebesar 0,009 $<0,05$, berarti dapat dikatakan bahwa ada interaksi antara model pembelajaran Realistic Mathematic Education (RME) dan Problem Possing serta kemampuan awal siswa terhadap hasil belajar matematika siswa.Hasil uji hipotesis ketiga ini dapat diinterpretasikan bahwa faktor model pembelajaran dan kemampuan awal dapat membawa pengaruh yang signifikan terhadap hasil belajar. Dalam penelitian ini rata-rata (mean) dari hasil belajar matematika dari model pembelajaran Realistic Mathematic Education (RME) lebih tinggi daripada pembelajaran Problem posing, dan bila dilihat berdasarkan kemampuan awal yang dimiliki siswa, maka dapat dikatakan bahwa hasil belajar siswa-siswi yang memiliki kemampuan awal tinggi lebih baik dibandingkan hasil belajar siswa yang memiliki kemampuan awal rendah. Jadi, dapat disimpulkan bahwa secara bersama-sama model pembelajaran dan kemampuan awal siswa berpengaruh terhadap hasil belajarnya.

Model pembelajaran $R M E$ merupakan model pembelajaran yang berorientasi pada hal-hal yang nyata dan kontekstual di dalam kehidupan siswa sehingga siswa merasa lebih familiar dengan materi yang dipelajari. Hal ini sangat penting untuk mengembangkan pemahaman dan daya nalar siswa tentang Matematika sehingga dapat membantu siswa di dalam memecahkan masalah di dalam kehidupan sehari-hari. Pembelajaran menggunakan model pembelajaran $R M E$ dapat memberikan gambaran yang lebih konkret sehingga siswasiswi lebih mudah dalam memahami materi pembelajaran. Namun tentang model pembelajaran problem posing juga tidak kalah menarik karena siswa bisa menjadi lebih aktif. Dengan demikian kedua model pembelajaran ini sangat cocok diterapkan dalam pembelajaran matematika. Temuan ini didukung hasil penelitian (Hodiyanto at el., 2016) bahwa Prestasi belajar siswa yang diberikan model pembelajaran PP dengan pendekatan PMR sama baiknya dengan prestasi belajar siswa yang diberikan model pembelajaran PS dengan pendekatan PMR. 


\section{KESIMPULAN}

Berdasarkan uraian dari pembahasan dan hasil, maka dapat disimpulkan bahwa:

1. Ada perbedaan hasil belajar Matematika antara kelompok siswa yang diberi perlakuan menggunakan model pembelajaran Realistic Mathematic Education (RME) dan Problem Possing pada siswa.

2. Ada perbedaan hasil belajar Matematika antara kelompok siswa yang memiliki kemampuan awal tinggi dan kemampuan awal rendah pada siswa. Hal ini ditunjukkan oleh rata-rata hasil belajar siswa yang memiliki kemampuan awal tinggi lebih baik daripada rata-rata hasil belajar kelompok siswa yang memiliki kemampuan awal rendah.

3. Ada interaksi antara model pembelajaran Realistic Mathematic Education (RME) dan Problem Possing serta kemampuan awal siswa terhadap hasil belajar matematika siswa

\section{DAFTAR PUSTAKA}

Hobri. (2009). Model-Model Pembelajaran Inovatif. Jember: Pesona Surya

Hodiyanto, Budiyono \& Iskandar Slamet. (2016). Eksperimentasi Model Pembelajaran

Problem Posing dan Problem Solving dengan Pendekatan PMR terhadap dan

Kemampuan Komunikasi Matematis ditinjau dari Kreativitas Siswa Kelas VII SMP

Negeri di Kabupaten Sukoharjo. Jurnal Elektronik Pembelajaran Matematika, ISSN:

2339-1685, Vol 4 No 2. Hal 199-214, from http://jurnal.fkip.uns.ac.id

Mahmudi,Ali. (2008). Pembelajaran Problem Posing untuk Meningkatkan Kemampuan

Pemecahan Masalah Matematika. (Makalah yang disampaikan pada Seminar Nasional Matematika Universitas Negeri Yogyakarta)

Muhhibin Syah. (2006) . Psikologi Pendidikan. Bandung: PT Remaja Rosda Karya.

Ratna, K. (2014). Pengaruh Model Problem Solving dan Problem Posing serta Kemampuan Awal terhadap Hasil Belajar Siswa. Jurnal Pendidikan Sains, ISSN: 2338-9117, Vol 2 No 4. Hal 184-192, from http://journal.um.ac.id/index.php/jps/

Ratnasari, \& Renni Eka. (2014). Realistic Mathematics Education (RME) terhadap Hasil Belajar Materi Dimensi Tiga Siswa Kelas X MA unggulan Bandung Tulungagung tahun Pelajaran 2013/2014. Skripsi. Tulungagung: IAIN Tulungagung. Tidak dipublikasikan.

Soedjadi. (2001). Kiat Pendidikan Matematika di Indonesia. Jakarta : Dirjendikti Depdiknas

Sugiyanti. (2006). Pengaruh pembelajaran menggunakan Pendekatan Realisthic Mathematic

Education (RME) pada Pokok Bahasan Bangun Ruang Sisi Lengkung Terhadap

Prestasi Belajar Matematika Ditinjau dari Kemampuan Awal Siswa Kelas VIII SMP.

Skripsi. Surakarta: Universitas Sebelas Maret Surakarta. Tidak dipublikasikan.

Suyatno. (2009) Menjelajah Pembelajaran Inovatif. Sidoarjo: Masmedia Buana Pustaka

Thobroni, M., \& Mustofa, Arif. (2011). Belajar Dan Pembelajaran: Pengembangan

Wacana Dan Praktik Pembelajaran Dalam Pembangunan Nasional. Jogjakarta: Ar-

Ruzz Media. 